\title{
IMÁGENES DE LA MUJER EN EL ROMANTICISMO DE ESPRONCEDA (SANCHO SALDAÑA)
}

\author{
RAQuel SANCHEZ \\ Universidad Complutense de Madrid \\ raquelsg@ghis.ucm.es
}

\section{RESUMEN}

La literatura romántica creó unos iconos acerca de la mujer que conformaron estereotipos que, en cierto modo, aún persisten. Un buen ejemplo lo tenemos en la novela Sancho Saldaña de José de Espronceda. Esta novela histórica de uno de nuestros principales románticos refleja en tres de sus personajes femeninos las imágenes predominantes de la mujer para el romanticismo: la mujer espiritualizada («musa mística»), la mujer pura objeto de amor ( «musa romántica») y la mujer perniciosa («mujer fatal»).

PALABRAS CLAVE: Romanticismo; Literatura española; Novela histórica; Imágenes femeninas.

\section{ABSTRACT}

Romantic literature created some feminine icons that, in some way, remain in force today. A good example is Espronceda's Sancho Saldaña. This historical novel shows us three stereotypes of women in the Romanticism: the sipritualised woman (the emystic muse»), the object of love (the «romantic muse») and the harmful woman (the afemme fatale»).

KEY WORDS: Romanticism; Spanish literature; Historical novel; Woman representations. 
La mujer es uno de los temas favoritos del romanticismo y su tratamiento, como puede suponerse, difiere un tanto de unos autores a otros. Sin embargo, podemos decir que hay una serie de arquetipos que se repiten y que, con distintas adaptaciones, han logrado conformar una imagen de la mujer que se asocia directamente con el romanticismo ${ }^{1}$. La musa romántica y el ángel del hogar son dos de los principales iconos creados en esta época, iconos que han perdurado a lo largo del tiempo y que se han acomodado a los requerimientos de la nueva sociedad. En líneas generales podemos decir que, siendo la mujer un asunto estrella entre los románticos, su presencia en la obra de poetas y novelistas es, más que habitual, omnipresente. Espronceda, uno de los románticos españoles más profundos, no iba a ser una excepción a esta regla.

El tratamiento de la mujer en la obra de Espronceda merece una atención especial, ya que su trabajo presenta unas características que lo singularizan en el panorama del romanticismo español. Por supuesto, Espronceda también recurre a las imágenes idealizadas de doncellas vaporosas e inalcanzables que tanto gustaban en la época, sin embargo, tales damiselas alcanzan en nuestro poeta una factura más honda, hay en ellas algo más que el reflejo de un sueño. Espronceda introduce en ellas un hálito de melancolía, un soplo de desconsuelo que hace suponer al lector que detrás de la ingrávida mujer hay un pasado de sufrimiento, hay una historia vivida de la que sólo queda el abatimiento después de la lucha y el consiguiente fracaso. Las mujeres de Espronceda parecen tener detrás de sí una rebelión contra el destino o contra la sociedad (que para el caso, viene a ser lo mismo) de la que sólo pueden salir derrotadas. Algunos autores han creído ver ahí un reflejo de la actitud de quien fuera la amante del propio poeta. Teresa Mancha, de la que el autor se separó de forma traumática y de quien, pese a los contradictorios sentimientos que parece experimentar en su "Canto a Teresa», al menos estimaba el intento de decidir su destino:

Espíritu indomable, alma violenta, en ti, mezquina sociedad lanzada a romper tus barreras turbulenta

Para Espronceda, como para todos su contemporáneos, la mujer está directamente asociada al amor, en forma idealizada o en su manifestación camal. Cuando se presenta en forma idealizada, le sirve a Espronceda para remitirse a un mundo de pureza, a un mundo donde no existe la materialidad. Así, el amor puro no es el amor físico, sino una especie de sentimiento de purificación que en obras como El estudiante de Salamanca se encarna en el personaje de Elvira:

Bella y más pura que el azul del cielo con dulces ojos lánguidos y hermosos, donde acaso el amor brilló entre el velo del pudor que los cubre candorosos; tímida estrella que refleja el suelo rayos de luz brillantes y dudosos, ángel puro de amor, que amor inspira, fue la inocente y desdichada Elvira

\footnotetext{
1 Acerca de estos arquetipos, puede consultarse el capítulo «En busca de una quimera. De la musa romántica al ángel del hogar» en Sánchez, Raquel: Románticos españoles. Protagonistas de una época, Madrid, Síntesis, en prensa.
} 
En esta concepción idealizada de la mujer y del amor coincide Espronceda con muchos de sus contemporáneos, aunque, como ya se ha dicho, tengan sus heroínas un toque de melancolía que no está tan presente en las musas de Zorrilla o de Bécquer². La otra imagen de la mujer es la de la mujer carnal, muy alejada, por tanto, del poder salvador del ideal. En el caso de Espronceda, este tipo de mujer se halla más próximo a personajes como Salada, de El diablo mundo, o a Jarifa, de $A$ Jarifa en una orgía. La primera representaría el instinto de lo natural, la erótica, sin connotaciones peyorativas ni morales, pero sí mostrando las ataduras que para el hombre libre supone la vinculación con lo sensual. Así se expresa en palabras de la propia Salada contemplando a su amante:

\title{
¡Oh! Sean mis manos cárcel de ese corazón que es mío, que no me lo robe nadie
}

Jarifa, por el contrario, se convierte en el reverso femenino del poeta hastiado del mundo y decepcionado, que resulta ser su única interlocutora posible tras el fracaso de sus ideales, como muestra en estos más que conocidos versos:

\author{
Ven Jarifa; tú has sufrido \\ como yo, tú nunca lloras. \\ Mas, jay, triste!, que no ignoras \\ cuán amarga es mi aflicción. \\ Una misma es nuestra pena, \\ en vano el llanto contienes.. \\ Tú también, como yo, tienes \\ desgarrado el corazón
}

En general, y en el conjunto de toda su obra, para Espronceda la mujer es como un mito lejano, un referente de poesía y pureza que queda destruido en su contacto con el hombre. La mujer es un icono de la inocencia, un sueño masculino que se rompe cuando ella misma traspasa la barrera de la ensoñación y se convierte en un ser real, cuando pretende cumplir las expectativas que sobre ella ha creado el hombre. Joaquín Casalduero, haciendo una trasposición desde el sexo a la trayectoria vital, señaló con acierto que en Espronceda: «lo femenino ha expresado la delicadeza, la ternura de la juventud; lo masculino es la forma de la crueldad y el dolor ${ }^{3}$.

2 Véanse al respecto algunos ejemplos: Díez Taboada, J. M.' (1965): La mujer ideal: aspectos y fuentes de las Rimas de Bécquer, Madrid. CSIC; Mayoral, Marina (1993): «El concepto de feminidad en Zorrilla» en Actas del Congreso sobre José Zorrilla. Una nueva lectura, Valladolid, Fundación Jorge Guillén-Universidad de Valladolid, pp. 125-140; Utrera, M.' V.: «La mujer romántica en la cosmovisión estética de Gustavo A. Bécquer" en Canterla, C. (1994) (coord.), La mujer en los siglos XvII y XIx, Cádiz, Universidad de Cádiz, 1994, pp. 629-637.

3 Casalduero, J. (1967): Espronceda, Madrid, Gredos, Madrid, p. 204. Casalduero hace estas reflexiones a partir del poema El estudiante de Salamanca, de los personajes don Félix de Montemar y doña Elvira. 


\section{Sancho Saldaña, novela histórica}

En el presente artículo se analizará el acercamiento de Espronceda al tema de la mujer a través de su novela Sancho Saldaña o el castellano de Cuéllar, publicada en 1834. La novela formó parte de la colección de novela histórica publicada por el editor Manuel Delgado para dar satisfacción al interés del público por los relatos ambientados en el pasado, género que había puesto de moda el novelista británico Walter Scott. Se ha señalado, incluso, que en el caso de esta novela de Espronceda, la influencia de Scott, sobre todo de Ivanhoe, resulta fundamental, restando originalidad al texto ${ }^{4}$. Sin negar esta evidencia (que existe en casi todas las novelas históricas de la época), no podemos restarle importancia en el conjunto de la obra de nuestro poeta.

Sancho Saldaña es una novela histórica ambientada en el siglo XIII que se ubica en el contexto de los enfrentamientos nobiliarios por las rivalidades entre Alfonso $X$ el Sabio y su hijo Sancho IV el Bravo. La novela presenta las vicisitudes de dos familias vinculadas a cada uno de estos reyes: los Íscar y los Saldaña ${ }^{5}$. El trasunto político es sólo una excusa de Espronceda para desplegar toda la iconografía romántico-medieval que tanto gustaba en el siglo xIX: castillos, tomeos, juglares, brujas, espectros, pasiones, etc. Los personajes de la novela forman una red de relaciones personales que, de forma paralela a las relaciones entre el rey y su hijo, han pasado de la amistad y del amor, al odio y al desafío. Sancho Saldaña, el principal protagonista, representa la imagen del héroe romántico, héroe satánico, esclavo de su obsesión por Leonor de Íscar, la hija de la familia rival, obsesión que desencadenará el drama de la novela y por la que todos los demás protagonistas se verán arrastrados de una forma u otra. En esta obra de Espronceda se entremezclan la pasión, la venganza, el honor y la locura, todos ellos temas relevantes en el imaginario romántico.

Las mujeres que van a ser centro de nuestra atención giran, precisamente, alrededor de la pasión desbocada y demente de Sancho Saldaña. Por una parte, conoceremos al personaje de Elvira, la hermana del protagonista y primera víctima de su atormentado carácter. Por otra parte, analizaremos a Leonor, el objeto de la pasión de Sancho Saldaña y hermana de Hernando, enemigo mortal del protagonista. La última de nuestras mujeres será Zoraida, antigua amante de Sancho, despreciada por éste al obstinarse con el amor de Leonor. Las tres forman parte de un caleidoscopio de imágenes que conforman la representación que de lo femenino pergeñó Espronceda en su obra artística. Alguna de ellas se repetirá en sus poemas y obras de teatro, de forma completa o tomando rasgos de carácter. Lo que parece evidente es que las tres mujeres de la novela construyen su personalidad alrededor de los sentimientos, y en especial del sentimiento del amor: del amor al

4 Así afirmó E. A. Peers (en «Studies in the influence of sir Walter Scott in Spain» Revue Hispanique, LXVIII (1926), pp. 1-160).

" Algunos estudios sobre la novela: Antón Andrés, A. (1981): «Estudio preliminar» a Espronceda, José de: Sancho Saldaña, Madrid, Taurus, tomo I, pp. 7-49; Ynduráin, D.: «Espronceda, novelista: Sancho Saldaña»: Koch, J.: «Paisaje y caminante: hacia una nueva lectura de Sancho Saldaña»; Gorlero, C. y De Miguel y Val, J. I.: «El amor y la política en Sancho Saldaña»; Gysi, M.: «Saber e imaginación en Sancho Saldaña» en Güntert, G. y Varela, J. L. (1986) (eds.): Entre pueblo y corona. Larra, Espronceda y la novela histórica del romanticismo, Madrid, UCM; Marrast, R. (1989): José de Espronceda y su tiempo, Barcelona, Crítica, pp. 329-348; Sebold, R. P. (2002): «Lágrimas y héroes en Sancho Saldaña», en La novela romántica en España. Entre libro de caballerías y novela moderna, Salamanca, Ediciones de la Universidad de Salamanca, pp. 141-157. 
hermano, del amor al amante. Todas ellas responden como un resorte al amor que se proyecta sobre ellas o al amor que se les retira y sus reacciones se verán determinadas por la acción de un elemento externo como será Sancho Saldaña. Si en general el romanticismo otorga al sentimiento un papel preponderante, por encima de la razón, cuando se trata de mujeres, esto es aún más evidente. La causa hay que buscarla en el vínculo que se establece entre lo femenino, lo instintivo y lo afectivo. Se profundiza entonces en el proceso de naturalización de la mujer (frente a la socialización del hombre) que ya impulsara Rousseau a finales del siglo XVIII .

Pero Saldaña, eje sobre el que ruedan los sentimientos de las mujeres de la novela, también es víctima del amor enfermizo: del que siente por Leonor y del que Zoraida proyecta sobre él. Saldaña, poseído por las pasiones, incapaz de razonar, se convierte en instrumento del rey a quien sirve: Sancho IV. Con ello, Espronceda nos desvela una contradictoria situación. Nos quiere presentar la doble faz de una humanidad en la que unos actúan movidos por sus más profundas pulsiones mientras que otros, con la fría razón como guía de sus actos, se aprovechan de ellos.

\section{Elvira, la musa mística}

Elvira es el nombre de la hermana de Sancho Saldaña. Sin embargo, poco sabemos de ella: una joven desaparecida tras la muerte de su padre y el asesinato del sacerdote que lo atendía a manos de su hermano Sancho, pecador impenitente. Al principio de la novela se hace referencia a ella mencionando vagos rumores acerca de una misteriosa aparición, de una mujer extraña a la que se denomina «la maga». Su primera aparición se sitúa en un marco tétrico: «En esto el viento había redoblado su furia y azotaba con pavoroso bramido la entrada de la caverna». Veamos el contexto en el que se sitúa la escena. Leonor ha sido secuestrada por una banda de ladrones. Su hermano Hernando y sus hombres la buscan por el bosque. Secuestrados y secuestrada se encuentran en una cueva, asustados por el estallido de la tormenta, cuando los ladrones gritan: «iLa maga!». Ahora se nos presentará a Elvira de la siguiente manera:

Un espantoso fantasma vestido todo de negro, con una antorcha en la mano, se apareció en este instante. Sus ojos lanzaban llamas, su semblante era lívido y sus brazos largos, secos y descarnados, semejaban a los de un desollado cadáver, mostrando todos sus músculos y ligaduras. Brillaba en medio de los relámpagos como un espectro rodeado de luz y vestido del nebuloso ropaje de las tinieblas?.

La escena es propia del gusto romántico por lo lúgubre y lo ultraterreno, por el mundo de los espíritus. Tras este primer perfil tenebroso de Elvira, la perspectiva se torna más amable y en sucesivas apariciones Espronceda nos la irá presentando en una imagen muy

" La situación de la mujer en el momento inicial del régimen libe: al ha sido analizada en artículos como los de Nielfa, Gloria (1995): «La revolución liberal desde la perspectiva de género» en Ayer, n. 17 , pp. 103-120 y Aguado, Ana (2003): «Género y ciudadanía en la formación de la sociedad burguesa» en Arenal. Revista de Historia de las Mujeres, vol. 10, n. ${ }^{\circ}$, pp. 61-79.

7 Espronceda, José de (1983), Sancho Saldaña, Madrid, Taurus, vol. 1, p. 103. 
cara al romanticismo: la espiritualización de la mujer en un proceso que la va acercando a Dios. En este caso, por la vía de la locura. En otra escena, Elvira ya va tomando cuerpo de lo que podríamos llamar «musa mística». Su hermano Sancho y Hernando de Íscar se han enfrentado con las armas y ambos están en el bosque gravemente heridos y solos. De pronto se presenta Elvira y «el espantoso fantasma» es ahora un:

...rostro pálido, y más ajado por el dolor y la penitencia que por los años, pues no parecía tener arriba de veintidós, tenía un no sé qué tan angelical y amoroso, que cautivaba y enamoraba con su ternura. Pero el sentimiento que inspiraba era más dulce y respetuoso que ardiente y apasionado, porque sin duda los pasatiempos de aquella joven no eran de este mundo y su alma ya habitaba en las celestiales mansiones de la paz y de la eterna felicidad ${ }^{\sharp}$.

Como vemos, Elvira ha adquirido ahora una definición más ajustada al carácter que Espronceda pretende otorgarle. Para los incultos e insensibles ladrones, para los labriegos, para los siervos, la aparición es un espectro, un fantasma. Para las almas sensibles, Elvira es una mística, mártir voluntaria de los pecados de su hermano.

Sin embargo, hay alguien que se da cuenta al instante del estado mental de Elvira, y ese alguien será el judío Abraham, deseoso de venganza. Abraham, disfrazado de sacerdote, tratará de manipular a Elvira para que sea ella quien consume su venganza matando a Sancho. Elvira, ajena a tales manejos, narra al judío Abraham sus deseos de suplicio, de martirio, de penitencia, para lavar la mancha de su hermano. Esta idea del sacrificio por los demás, espiritualizada en el sacrificio religioso, ocupa el lugar más alto en la consideración del romántico por la mujer. La mujer inaccesible, que ni siquiera puede ser concebida como objeto de amor y adoración porque sus miras están puestas en Dios, alcanza una dimensión casi incorpórea, por supuesto, totalmente alejada de cualquier carnalidad, es casi un espíritu. Este tipo de mujer, frecuentemente representada como una monja, es bastante habitual en otros autores románticos como Zorrilla con su doña Inés, aunque ésta comparte caracteres con la mujer objeto de amor. No lo es tanto en la obra de Espronceda, quien, por supuesto, también idealiza y sublima a la mujer ideal, pero se trata de una mujer que representa al amor, al amor que el romántico proyecta sobre una imagen de mujer construida por él mismo. La espiritualización de la mujer aproximándola a Dios no forma parte de los iconos esproncedianos, probablemente porque nuestro autor no manifestó nunca un interés muy grande por cuestiones religiosas. Incluso podríamos decir que Espronceda, por medio de sus poemas, es de los pocos románticos españoles que trata de desafiar al Dios omnipotente a través de personajes como Félix de Montemar (protagonista de El estudiante de Salamanca).

Ahí pudiera estar la razón por la cual la pasión mística de Elvira es presentada por Espronceda como una manifestación de locura. Efectivamente, Elvira va evolucionando en su demencia a lo largo de la novela, manifestando un desquiciamiento progresivo. En cierto episodio de la novela, Elvira se sincera con Leonor, revelándola quién ha sido su salvadora en la cueva, o sea, ella misma. Se produce entre ambas una conversación en la cual Espronceda nos confronta a la musa mística (Elvira) con la musa más propiamente romántica (Leonor). A través de Leonor, de cómo Leonor responde y recibe los comen-

\footnotetext{
${ }^{8}$ Ibidem, vol. 1, pp. 201-202.
} 
tarios de Elvira, nos vamos dando cuenta de hasta dónde alcanza el delirio de Elvira. Leonor no puede más que preocuparse y desconcertarse, pero a la vez es el espejo de la realidad, del sentido común del lector. Por supuesto, no deja de haber admiración hacia alguien que es capaz de sacrificar su propia vida por la de otra persona pero, y aquí se nota que Espronceda es un romántico mundano, el lector no llega a entender muy bien por qué un ser humano ha de desperdiciar su vida por otro que ni siquiera es consciente de tal sacrificio y que, para colmo, es tan malvado como Sancho Saldaña. Espronceda pone en duda la utilidad del sacrificio de Elvira. Estas palabras que Elvira le confía a Leonor son buena prueba de ello:

Entonces me postré delante de Dios, oré por el pecador y ofrecí sepultarme en vida, cubrir mi rostro y alejar de mi todas las vanidades del mundo para expiación de los crímenes de mi hermano. Desde entonces cambié mis galas por el cilicio, troqué la blandura de mi lecho por un poco de paja, comí las raíces de los árboles, los frutos silvestres y traté mi cuerpo como a un animal inmundo. Vime odiada y maldecida de los habitantes de las cercanías, creída bruja y mirada como un agente de Satanás ${ }^{9}$.

La identificación por parte del pueblo de Elvira como perteneciente al mundo de la brujería revela también esa incomprensión. Frente a ella, sitúa Espronceda la otra imagen de bruja que aparece en el texto: la tía Gila, personaje que vive marginado en un bosque. Sin embargo, ni siquiera para el pueblo son la misma clase de mujer, de hecho, la tía Gila es llamada «la bruja» y Elvira «la maga». Las connotaciones negativas de la primera palabra no se hallan en la segunda. Ambas representan las dos caras del mundo de lo oculto, pero queda también manifiesta la contraposición entre lo bueno y lo malo, la entrega a Satanás o la entrega a Dios. La tía Gila es una mujer resentida, que realiza conjuros y desea el mal a los que son felices debido a su derrota personal. Elvira, por el contrario, es una joven que, como vimos, se ha sacrificado por la salvación de su hermano Sancho sin haber apenas vivido. La tía Gila es una mujer fracasada; Elvira es una víctima ${ }^{10}$.

En definitiva, el personaje de Elvira viene a representar la sublimación a través de la entrega y el sacrificio, un personaje que representa una bondad exagerada que no puede desembocar más que en la locura. Elvira se vuelve loca por incomprensión del mundo que la rodea, por su incapacidad para entender la destrucción de los afectos familiares de su entorno ${ }^{11}$. Su locura le lleva a adoptar un papel netamente femenino: sacrificarse ella para salvar a su hermano, sacrificio que para el autor resulta inútil. Tal sacrificio no es, en última instancia, más que uno de los caminos que se ofrecían a la mujer: la realización a través del otro.

Ibidem, vol. 1, p. 211.

10 Ambas aparecen situadas en el contexto de un bosque, lo que contribuye, junto a otros elementos, a dotar a éste de un carácter mágico en el desarrollo de determinados episodios. C. Gorlero y J. I. de Miguel y Val han estudiado esta peculiaridad de Sancho Saldaña en «El amor y la política en Sancho Saldaña» en Güntert, G. y Varela, J. L. (1986) (eds.), Entre pueblo y corona..., pp. 143-153. Desde una perspectiva más amplia: Camero, G. (1973): «Apariciones, delirios, coincidencias: actitudes ante lo maravilloso en la novela histónica española del segundo tercio del siglo XIX», en Insula, n. 318 , pp. 13-15.

1 Es necesario señalar que resulta fundamental en el carmino a la locura de Elvira el hecho de que, estando a punto de morir su padre y pidiendo éste la presencia de Sancho para darle una última bendición, Saldaña decida ignorar la llamada de su padre y prefiera permanecer con su amante Zoraida. 


\section{Leonor, la musa romántica}

Leonor es la hermana de Hernando de Íscar, antigua prometida de Saldaña, cuyo compromiso quedó roto por el enfrentamiento entre las familias y la vida patibularia de Saldaña. En la novela, Leonor representa el papel de la musa romántica por antonomasia. Se trata de un personaje pasivo sobre el que recaen las acciones de los demás, y especialmente las de su hermano y Saldaña. En ella queda depositada la honra del linaje de los Íscar y la obsesión amorosa de Saldaña.

Al principio de la novela, Espronceda nos muestra a Leonor en una cacería, con su hermano y otros cazadores. Aún es Leonor una dama fuerte y confiada, cuya habilidad como amazona le permite salvar la vida de su hermano Hernando cuando el caballo de éste se desboca:

Seguida de su hermano y algunos otros, aguijaba un generoso caballo tordo con tanta bizarría y atrevimiento como el cazador más experimentado, y a su agilidad y a la presteza de su carrera se la habría podido tomar por una sífide, volando en alas del viento, llena de belleza y gallardía. Cualquier mal paso que se ofrecía a su camino, cualquier zanja, era ella la primera que la saltaba, a pesar de los gritos de su hermano, que trataba de contenerla, y con admiración de todos los que la veían ${ }^{12}$.

Contrasta esta Leonor activa y segura de sí misma con la dama turbada y mortificada que veremos después. A lo largo de la novela, se irá cuarteando el mundo de seguridad que la rodeaba antes de los acontecimientos que se narran: desaparecerá la paz de su vida, huirá la confianza de su hermano, será sacada de su castillo para ser depositada en otros entornos que le son ajenos, como la cueva en el bosque o el castillo de Saldaña. De este modo, su trabada identidad como heredera de una antigua familia, merecedora de todos los respetos y consideraciones por su condición de dama, se irá diluyendo y sólo le quedará la inocencia de su corazón que es, precisamente, lo que Saldaña busca en ella. Poco a poco, en Leonor las imposturas sociales dejarán paso a los dones naturales.

Por tanto, y volviendo al argumento de la novela, comenzamos viendo a Leonor en una cacería. Es Leonor una mujer feliz al lado de su hermano, cuando tiene lugar el secuestro por parte de los sicarios de Saldaña. A partir de ese momento se produce el drama, en el que la protagonista va a adquirir un carácter especular en el que se reflejan los dos personajes masculinos principales. De cara al público lector, Leonor es una dama digna de lástima, víctima de las añejas ideas acerca del honor que posee su hermano y víctima también de la monomanía de Saldaña. Para éste último, en Leonor se contienen todos los méritos y valores que él ya no posee: la dulzura, la belleza de alma, la bondad, etc. Todos ellos valores asociados a una imagen de mujer angelical, pero no como Elvira, sino una mujer para ser amada. El mismo Saldaña lo siente así en un momento de la novela: «...al mismo tiempo que aumentaba su desesperación el horrible contraste que ofrecían su corazón y el de ella si los comparaba» ${ }^{13}$. El objetivo de Saldaña es casarse con Leonor para así poder limpiar su alma de los pecados cometidos anteriormente, conce-

${ }^{12}$ Espronceda, José de (1983): op. cit., vol. I, p. 84.

${ }^{13}$ Ibidem, vol. II, p. 76. 
diendo a la dama el papel de redentora. Las apelaciones al amor que hace Saldaña no son en realidad más que un deseo de retornar a un tiempo de supuesta inocencia en que su corazón no se había revolcado en el fango de las pasiones. Leonor recuerda para él aquella época de su existencia y por medio del matrimonio con la dama pretende traer los tiempos pasados al presente. Así, dirá Saldaña:

Un recuerdo, dulce como el aroma de las flores, me quedaba aún; un recuerdo que podía traer a mi memoria sin horrorizarme ni estremecerme. Tú, joven hermosa, virgen pura; tú sola podías hacer mi felicidad; tú eras la llama de mi existencia; yo te veía en todas partes, para mi no había ya soledad, porque tú siempre me acompañabas. ¡Ah!. Yo necesitaba de ti, de ti para que fueses el rocío de mi alma; pero tú me desdeñabas. ¿Qué me quedaba que hacer?. Robarte para poseerte; ahora soy tu esclavo ${ }^{14}$.

En realidad se trata de una figuración más de Saldaña, quien en su egoísmo no es capaz de entender el profundo aborrecimiento que la protagonista siente hacia él. Cuando Hernando de Íscar cae prisionero del rey Sancho IV, Saldaña ve la oportunidad de ejercer el chantaje sobre Leonor: prometerle la salvación de la vida de Hernando a cambio de su mano.

Comienza en ese momento una terrible agonía para Leonor, que se va a ver presa entre su obligación como miembro de una antigua familia y sus sentimientos hacia su hermano. Espronceda sabrá conducirnos a través de este drama moral de gran atractivo para los lectores del romanticismo, drama que revela la dualidad entre la sociedad y el individuo: la rigidez de las normas y la expresión de unas emociones plenamente humanas. En una significativa conversación entre Leonor y Saldaña, veremos revelarse ambos caracteres: el de ella en su inflexible rechazo a las demandas de él (necesario para mostrar ante el lector la entereza de su carácter); el de él: su obstinación por saltarse el código moral al que se supone que debe responder un caballero. Se expresan en dos lenguajes distintos: ella presupone en Saldaña el comportamiento con respecto a una dama que se debe esperar de alguien de su alcurnia; él habla como un obseso de su deseo de purificación por medio del matrimonio. Al darse cuenta de la falta de entendimiento, Leonor responderá: «te creía criminal, pero caballero», señalándonos que Saldaña había saltado ya todas las barreras de la conducta caballeresca. En determinado momento, Saldaña traslada la culpa de todo lo que suceda a Leonor, acusándola de ser ella la que va a provocar el terrible desenlace si se niega a aceptar su proposición de matrimonio:

Mil veces te he dicho que te idolatro, y te he pintado el amor de fuego con que has abrasado mi alma. No me hables de generosidad, no me pidas por él: es inútil; eres tú quien le ha de librar, y yo no he de ser sino el instrumento de tu voluntad. Mentiría si te ocultase que puedo fácilmente salvarle; pero no, Leonor, tú no has sido generosa conmigo; tú me has visto a tus pies triste, afligido y acosado de mil tormentos; te he pedido, no que me libertases de una muerte pronta, sino una lágrima de piedad, mi felicidad en la tierra y la salvación de mi alma's.

\footnotetext{
14 Ibidem, vol. I, p. 267.

is Ibidem, vol. II, p. 177.
} 
En páginas posteriores, Leonor mantendrá otra conversación significativa, esta vez con su hermano, prisionero del rey. A través de ella veremos cómo se plantea el reverso de la moneda: veremos a un Hernando atrapado por los requerimientos de un rígido convencionalismo social, la honra, que le lleva a exigir a su hermana una serie de actitudes, para denigrarla con los peores calificativos cuando ella muestra alguna reticencia (reticencias que sólo pretenden protegerle). Habiéndose enterado Hernando de que su hermana se muestra dispuesta a casarse con el malvado Saldaña para salvarle la vida, le grita: «Tú me has perdido y te has llenado de infamia a ti misma». Leonor vuelve a verse al margen del código de honor en el que habla su hermano, en el que no creer percibir el gran sacrificio que ella está dispuesta a hacer por él:

Yo he suplicado a Saldaña que me permitiese venir a verte pensando servirte de consuelo, y he venido sólo a aumentar tu martirio. ¡Dios mío!. ;Qué maldición ha caído sobre mi para merecer el odio de mi hermano!. ¿Quién hay más desdichada que yo!. ¿Qué quieres que haga por ti? ${ }^{16}$.

Hernando permanecerá dentro de su inflexible moral durante toda la conversación sin prestar apenas atención a los sentimientos que le expone la hermana y utilizando armas dialécticas muy duras contra ella:

Vete, vete de aquí, primero que me hagas cometer un crimen, ahogándote para evitarte que cometas tú una vileza, y sabe que te he maldecido, que en ti no veo ya sino una prostituta que va a entregarse a un malvado, que antepone la vida a la honra, y que ha venido, en fin, a amargar mi última hora con su presencia. Sí, yo te maldigo y hasta que muera te maldecirén ${ }^{17}$.

Espronceda incide repetidas veces en la incomprensión general hacia el sacrificio de Leonor: ni su hermano ni los hombres que aparecen en la novela son capaces de compadecerse de ella ni un instante. Ni siquiera uno de los personajes secundarios, Usdróbal, al que Espronceda otorga gran importancia, pues representa el idealismo juvenil. Usdróbal considera a Leonor como una especie de amor platónico, que ha dado a su vida una orientación caballeresca y le ha elevado por encima de su condición de pícaro ${ }^{18}$. Cuando llega la noticia del compromiso de Leonor, los sentimientos de Usdróbal son descritos por el autor de la siguiente manera:

No menos irritaba el amor a Usdróbal que al caballero la honra, y no parecía sino que un mismo sentimiento los animaba. Había reventado en el corazón del primero el volcán de los celos, hasta entonces sofocado por el respeto que su mismo amor y la noble condición de Leonor le inspiraban, $y$ aunque había dado siempre por mentidas ilusiones sus esperanzas, y nada le había ella primero en su vida, tachábala de ingrata y maldecía su inconstancia, no pensando sino en que iba a poseerla otro hombre, mientras él, por premio de su cariño, no había merecido siquiera una mirada de compasión ${ }^{19}$.

${ }^{16}$ Ibidem, vol. II, p. 212.

17 Ibidem, vol. II, p. 213.

18 En el estudio ya citado de R. P. Sebold, este crítico lleva a cabo un interesante análisis distinguiendo en la novela objeto de nuestro interés entre el héroe moral (Usdróbal) y el héroe artístico (Saldaña).

${ }^{19}$ Espronceda, José de (1983): op. cit., vol. II, p. 238. Aquí Espronceda comete un anacronismo, trasponiendo comportamientos del siglo XIX al siglo XIII. Siendo Usdróbal un joven de clase baja, en la Edad Media jamás hubiera podido aspirar a casarse con una mujer de la nobleza, de lo que él mismo es consciente en otras partes de la novela. 
Es en las escenas en las que Leonor interacciona con los hombres, sobre todo con su hermano, donde más palpable es la presencia de anacronismos en la novela. Espronceda hace hablar a Leonor un lenguaje del siglo XIX, la conduce a expresar unos sentimientos propios del romanticismo, mientras que su hermano parece un personaje sacado de la España calderoniana. Son los momentos más críticos, que más peligro plantean en la novela, por cuanto el lector no acaba de entender la intransigencia de Hernando ni su incomprensión hacia la situación de su hermana. El talante del lector decimonónico permanece alejado de tales fanatismos, pese a que con ellos el autor pretende marcar más duramente la soledad de la protagonista, cargando las tintas en la rigidez de la sociedad (pese a correr un peligro evidente de pérdida de sentido). Resulta más accesible, sin embargo, entender la relación que se establece entre Leonor y Saldaña, relación conflictiva, bien es cierto, pero mucho más próxima a la sensibilidad del momento, pues ambos personajes responden a arquetipos románticos. De ahí que en la conversación entre ambos no tengamos la sensación de desubicación que es palpable cuando Espronceda enfrenta a la protagonista con su hermano, pues el lenguaje que hablan se mueve en un mismo código expresivo y comunicativo.

\section{Zoraida, la mujer fatal}

Zoraida es, tal vez, el personaje femenino que más interesa a Espronceda. A lo largo de la novela, el autor se complace en irla presentando en toda la complejidad de su carácter, alcanzando una profundidad que no está presente en las demás mujeres. Zoraida es una mujer volcada al amor, al amor pasional. Su amor por Saldaña es pura obsesión morbosa. Cuando éste la abandona para ir detrás del imposible afecto de Leonor, Zoraida se alza con toda esa pasión en la búsqueda obsesiva de la venganza. Al contrario que Elvira y sobre todo que Leonor, Zoraida es una mujer activa, cuya actividad gira, desde luego, alrededor del hombre, pero que en vez de esperar el impulso masculino, toma la iniciativa en su camino hacia el desquite ${ }^{20}$.

Ya en la descripción de su aspecto físico, Zoraida tiene unas características que la alejan de las musas románticas (etéreas y vaporosas) para adquirir una carnalidad que le da una dimensión distinta: «Había sido cautiva Zoraida cuando apenas rayaba en los quince años y era lo que podía llamarse un modelo de hermosura árabe. De airoso continente, alta y briosa de cuerpo, su marcha era la del águila que desafía al sol frente a frente» ${ }^{21}$. El hecho de que su origen (supuestamente musulmán, aunque en realidad es judía) no sea el mismo que el de las demás mujeres y hombres que la rodean, excusa al autor para permitirle actuar al margen de los comportamientos establecidos, $y$ sobre todo para que, siendo una mujer, pueda manifestar sus deseos amorosos con entera libertad. Y

${ }^{20}$ R. Marrast ha establecido una comparación entre Zoraida y otro personaje esproncediano, Blanca de Borbón (protagonista de la obra teatral del mismo nombre). Ambas aman a dos hombres que son profundamente ingratos con ellas y que las abandonan (Zoraida es abandonada por Saldaña y Blanca por el rey Pedro el Cruel). La reacción de las dos mujeres es, sin embargo, muy diferente: mientras que Blanca opta por la resignación, Zoraida buscará la venganza (Marrast, Robert, José de Espronceda..., pp. 332-333).

21 Espronceda, José de (1983): op. cit., vol. I, p. 113. 
así, Espronceda nos relata su pasión por Saldaña, inexplicable comportamiento en otro tipo de mujer:

Amaba (no, amaba, es poco), deliraba, idolatraba, miraba a Sancho Saldaña como a su Dios, como a su todo, y a consecuencia de tanto amarle, su mismo frenesí, su mismo amor rayaba en aborrecimiento, de suerte que le odiaba y le idolatraba a un tiempo, y a un tiempo le arriesgaba y le protegía, le despreciaba y le defendía, buscándole y huyendo de él, insultándole y acariciándole, y sintiendo afectos tan diferentes con la misma violencia que la pasión frenética que los movía ${ }^{22}$.

La pertenencia de Zoraida a una religión diferente también le permite al autor dar rienda suelta al gusto decimonónico por lo orientalizante como metáfora de lo exótico y nos la describe en sus habitaciones, que parecen ser un oasis de refinamiento al lado de las recias y austeras estancias de los cristianos:

De repente se abrió una puerta que daba a una sala de tocador adornada de espejos de Venecia, ricas alfombras y cojines a la morisca, con rejas a un delicioso jardín, donde brillaba el último rayo del sol poniente, $y$ mil olorosos perfumes y voluptuosos aromas se esparcieron, como de una encantada mansión...23.

Parece establecerse un paralelismo entre la sobriedad (en ciertos casos, tal como la describe el autor, más próxima a la rusticidad que a la elegancia) de la vida de los cristianos con la entereza (o unilateralidad) de su carácter, y entre el sibaritismo del entorno de la musulmana con la complejidad de sus sentimientos. El de Zoraida no es un carácter de una pieza, sino que, por el contrario, presenta la complejidad de lo inestable, de lo extremado en el amor y en el odio y eso, como ya hemos dicho, la diferencia de las otras mujeres, como el propio Espronceda se encarga de anunciarnos:

Todo su traje era a la usanza mora, blanco y carmesí, como su turbante, lo que la hacía sobremanera bellísima, aunque en sus ojos negros y penetrantes se veía el ánimo y el orgullo, en vez de la dulzura propia de los ojos de las hermosas. Con todo, en este momento se dejaba ver en los suyos la expresión del dolor al través de la que le era natural, y en su enérgica y hermosísima fisonomía se mostraban claramente las señales de su tristeza ${ }^{24}$.

La marginalidad en la que se mueve Zoraida la convierte también en objeto de agresión. El paje Jimeno, deseoso de obtener sus favores y viéndose rechazado por ella, la denuncia acusándola de bruja y de haber hechizado al señor de Cuéllar, sin que Saldaña ponga el menor reparo en ello. Zoraida es entregada al tribunal que la juzgará. A partir de este momento se convertirá en uno de los símbolos de la opresión de la sociedad a los que son diferentes, personajes tan frecuentes en la obra de nuestro poeta y cuyo mejor representante es Adán de El diablo mundo. A través de esta Zoraida apresada, a la que se amenaza de tortura y a la que se le leen las acusaciones en latín (idioma que ella desconoce), Espronceda nos va a mostrar su talante rebelde y crítico. Será precisamente

\footnotetext{
22 Ibidem, vol. I, p. 113.

23 Ibidem, vol. I, p. 161.

24 Ibidem, vol. I, p. 162.
} 
cuando Zoraida sea llevada al juicio cuando aparezca su padre, en una escena melodramática digna de la época en la que se escribió la obra. Finalmente, se apelará al juicio de Dios, y Zoraida logrará la salvación por la intervención de un disfrazado Usdróbal que se encuentra en camino de convertirse en caballero.

Tras los acontecimientos del juicio, Zoraida se verá libre, aunque se habrá acentuado su desvarío, apareciendo con frecuencia como un fantasma, de forma oculta, siguiendo los pasos de Saldaña. Vemos cómo, de nuevo y a pesar de haberse reconocido su inocencia, Zoraida vivirá en la marginalidad. En una de las ocasiones en que se aparezca frente a Saldaña, éste, queriendo deshacerse de su pasado, le clava una daga en el pecho. A partir de ahora, apenas sabremos nada de Zoraida hasta que de nuevo aparezca como un fantasma ante Saldaña quien, creyéndola muerta, sufrirá una gran conmoción. Tampoco el lector sabe si la visión de Saldaña es el espíritu de su antigua amante o es ella misma. Espronceda, para jugar con lo sobrenatural, tan del gusto romántico, hace que la escena sea sólo vista por Saldaña, pese a estar rodeado en ese momento por la corte del rey Sancho. La última aparición de Zoraida será en la boda entre Saldaña y Leonor, momento en que, movida por su deseo de venganza, clave un puñal a la atribulada novia y acabe con su vida.

En definitiva, podría decirse que tenemos en Zoraida un preludio de lo que más adelante será la mujer fatal, es decir, la mujer de belleza perturbadora, que conduce al hombre a la perdición. Hay, de forma añadida, elementos que nos permiten ampliar esta perspectiva. Vemos en Zoraida el discurrir de una pasión que está por encima de su razón, por encima de la protección de su propia vida, lo que la convierte, no cabe duda, en un personaje plenamente romántico. Es esa pasión la que le lleva a clamar por el sentimiento como algo que está más allá de la capacidad de control del hombre (de la mujer, en este caso). La expresión de afectos de Zoraida no es nunca contenida, y en el momento de publicación de la novela debió causar gran sensación en el público por el extremo al que llega. Es muy probable que Espronceda, deseoso de experimentar con esta idea, decidiera servirse de un personaje femenino para mostrar los extremos del sentimiento romántico, pues la posibilidad de hacer creíble ese comportamiento en un hombre resultaba bastante remota, sobre todo en el contexto cultural español.

Para ello fijémonos en escenas como la que se describe a continuación. Hay un momento en que Zoraida, en una demostración de humillación completa, le dice al Saldaña: «Pero si tú me vuelves tu amor -continuó, cambiando el tono enérgico con que hablaba y modulándolo dulcemente-, entonces yo te idolatraré, yo seré tu esclava. Mírame, Saldaña, a tus pies, vuélveme tu cariño» ${ }^{25}$. Semejantes palabras nunca hubieran podido ser pronunciadas por un personaje literario masculino en la España del siglo XIX, entre otras cosas porque implicarían un interlocutor femenino en posición de dominación, y esto era algo absolutamente inconcebible. Lo único que podemos esperar de Saldaña es la culpabilización de Zoraida como productora de sus males: «Tú me has dejado sin alma, has agotado en mi el sentimiento, y si alguno ha quedado en mí, es sólo el del egoísmo. ¡Ah!. ¡Por qué, si fue un sueño mi felicidad contigo, no expiré yo antes de despertar! $»^{26}$. Recordemos que Saldaña ya utilizó este recurso de la culpabilización de la mu-

${ }^{25}$ Ibidem, vol. I, p. 165.

26 Ibidem, vol. I, p. 165. 
jer con Leonor, lo que muestra la tendencia de una sociedad y, en este caso, de un autor, a focalizar la potencial perturbación de la armonía social y familiar en el sexo femenino, actúe éste de forma activa o de forma pasiva.

El uso de un personaje femenino para explorar los extremos del sentimiento también le resulta de utilidad a Espronceda para analizar el amor como emoción morbosa. La novela nos muestra cómo el grado de ofuscación de Zoraida se va agravando con el paso del tiempo y con los desplantes de Saldaña. Su obsesión se va agrandando y se acaba convirtiendo en monomanía. Tendremos un buen ejemplo de hasta dónde ha llegado su locura cuando el padre de Zoraida, Abraham, sea apresado y ella decida ir a ayudarlo:

Su amor a Saldaña había sido el primero, el único amor de su corazón, y ahora no podía por menos de confesarse, con vergüenza, que la libertad de su padre era sólo un pretexto con que quería en vano engañarse a si misma, para ocultarse la fuerza de su pasión y el poder del destino que la arrastraba a Cuéllar ${ }^{27}$.

De este modo, y en una línea muy propia del romanticismo, el amor aparece como una fuerza arrebatadora capaz de ir más allá de los requerimientos de la naturaleza, que conducirían a la protagonista a situar el amor a su padre por detrás del amor al hombre que ha destruido su vida. La conducta de Zoraida, por tanto, no estará nunca guiada por la razón, sino por el sentimiento, lo que le hace saltar por encima de todas las convenciones sociales y de sexo. El carácter subversivo de tal sentimiento en el romanticismo es un elemento clave para entender las críticas de inmoralidad que tantas obras teatrales y novelas sufrieron en el $\mathrm{XIX}^{28}$.

Por lo tanto, en esta novela, y a diferencia de otras obras románticas, el arquetipo de mujer fatal alcanza una profundidad mayor pues, como hemos visto, le sirve al autor para mostrar un personaje al margen de la sociedad, que es a la vez víctima y verdugo. Por otra parte, su confrontación de Zoraida con Saldaña no es simplista, pues si bien ella ejerce un papel de seducción y perdición, también es cierto que Saldaña es un personaje satánico, un hombre volcado hacia la locura y Espronceda no nos le muestra en ningún momento como una víctima de las arteras mañas de una mujer oscura. Por el contrario, ambos parecen utilizarse mutuamente para lanzarse al vacío: ella por un amor obsesivo y él por un hastío vital.

\section{CONCLUSIÓN}

En el capítulo XV nos ofrece Espronceda una escena en la que podemos ver juntos a las tres mujeres y a Saldaña. Cada una de ellas respondiendo a la perfección a la representación que el autor ha querido mostrar. La escena narra el episodio en que Saldaña va a ver a Leonor presa en su castillo. Al poco tiempo de conversación, aparece su hermana, a la que el protagonista no reconoce en un principio. Después, surge entre la oscuridad

${ }^{27}$ Ibidem, vol. II, p. 181.

2* El mismo Mariano José de Larra censuró la obra Antony de Dumas en sus artículos para El Español (junio de 1836) precisamente por situar al sentimiento amoroso por encima de la convención social. 
Zoraida increpando a Saldaña, el cual intenta asesinarla. Ante semejante acto, Leonor le grita a Saldaña: « ¿Es acción digna de un caballero poner la mano en una mujer?». Elvira le conmina a retirarse bajo la expresión «si tienes algún temor de Dios». Zoraida, por su parte, le reta a acabar con su vida y le amenaza con perseguirle después de muerta: «Te engañas si piensas por eso libertarte de mi». Estamos, en definitiva, ante los tres clichés que ya hemos comentado a lo largo de estas páginas.

Las tres mujeres son, en última instancia, representaciones que el propio Espronceda se hace de lo femenino. Sin embargo, también podemos ver en tales representaciones las tres fases de la relación hombre-mujer o tres formas de concebir el amor para los románticos. La primera, en el papel de Elvira, sería la idealización máxima, desprovista de carnalidad. Un tipo de amor que sólo puede sentirse hacia una hermana o hacia una monja. La segunda, Leonor, es el amor platónico, también idealizado, pero siendo una mujer ajena a la familia el centro de atención. Éste es el amor romántico por antonomasia. La tercera, Zoraida, es (ha sido, mejor dicho) la amante. Aquí nos encontramos con el amor que lastra, con el amor obsesivo, con el amor enfermizo, con las consecuencias del amor cuando se traspasa la segunda fase. En este momento la mujer se ha enfangado en la pasión y se ha perdido. Es el momento de la verdad, el momento en que el ideal no puede ocultar la fugacidad del amor. En cierto modo, y a tenor de las siguientes palabras de Zoraida, podríamos concluir diciendo que Espronceda culpará al amor consumado de la pérdida de la inocencia:

No le ames, mujer — prosiguió dirigiéndose a Leonor-, no le ames; su lengua es engañosa, su corazón es malvado, y él te engañará y hará del tuyo un infierno, como ha hecho del mío, y como hace que sea cuanto está junto a él; no le ames, si no quieres como yo hundirte con él en el abismo de su perdición. Mira, yo era feliz — continuó con acento melancólico-; yo era inocente como tú; como tú he sido robada; me amó, le amé, y ya fui viciosa, criminal y despreciable para todo el mundo ${ }^{29}$.

${ }^{29}$ Ibidem, vol. I, p. 268. 